\title{
Effect of Syzygium cumini leaves on laying hens performance and egg quality
}

\author{
EDNARDO R. FREITAS, DANILO R. FERNANDES, DAVYD H. SOUZA, FRANCISCO D.T. DANTAS, \\ REBECA C. SANTOS, GILSON B. OLIVEIRA, CARLOS EDUARDO B. CRUZ, NÁDIA M. BRAZ, \\ LORENA F. CÂMARA, GERMANO A.J. NASCIMENTO and PEDRO H. WATANABE
}

Departamento de Zootecnia, Centro de Ciências Agrárias, Universidade Federal do Ceará, Avenida Mister Hull, 2977, Caixa Postal 12168, 60021-970 Fortaleza, CE, Brazil

Manuscript received on May 11, 2015; accepted for publication on August 18, 2015

\begin{abstract}
The aim of this study was to evaluate the effect of Syzygium cumini leaves (SCL) in laying hens diets on productive performance, egg quality and lipid oxidation of yolk. A total of 108 Hysex White laying hens were distributed in a completely randomized design with three treatments and six replicates of six birds each. The treatments consisted of SCL inclusion at dietary levels of 0,5 and $10 \mathrm{~g} / \mathrm{kg}$. There was no significant effect of SCL inclusion on feed intake, laying percentage, weight and egg mass, feed conversion ratio, Haugh units, specific gravity, percentage of yolk, albumen and egg shells and shell thickness. However, the inclusion of SCL significantly influenced the yolk color and yolk lipid oxidation measured by TBARS values. Yolk color increased and TBARS values decreased with the inclusion of SCL. The inclusion of SCL in laying hens diets improves pigmentation and lipid stability of yolk.
\end{abstract}

Key words: antioxidant, egg quality, phytogenic additives, yolk color.

\section{INTRODUCTION}

The most frequent deterioration that occurs in foods is lipid oxidation. It affects the quality, flavor, taste and nutritional value and produces toxic compounds. Thus, the use of antioxidants in the feedstuffs or in feed aims to protect or maintain nutritional and energy values of diets (Mariutti and Bragagnolo 2009), being possible to have an extensive effect to the food. For this purpose, synthetic antioxidants commonly used in diets are butylated hydroxyanisole (BHA) and butylated hydroxytoluene (BHT). However, studies have shown that these compounds may have some

Correspondence to: Ednardo Rodrigues Freitas

E-mail: ednardo@ufc.br toxicity, resulting in search for natural antioxidants to replace them (Freitas et al. 2013), with focus on phytogenic additives. The phytogenic additives for use in animal feed can be herbs, whole plant or its parts, extracts or essential oils from plants. When added in diets, these additives can provide improvement in feed intake, weight gain, increase digestive secretions and also a protection to damage from oxidative stress due to the antioxidant activity (Ahn et al. 2002).

Studies have been performed to evaluate the inclusion of parts or plant extracts that had already proven in vitro antioxidant activity in laying hen diets on performance and improvement in egg quality (Botsoglou et al. 2012, Freitas et al. 
2013), demonstrating the beneficial effects on lipid stability. In this sense, the Syzygium cumini, popularly known as "jambolão", "azeitona preta" or "guapê" is a plant belonging to Myrtaceae family plant which different parts are described in the literature by presenting medicinal properties due to different chemical constituents, such as gallic acid, metilgalatic, kaempferol, myricetin, ellagic acid, chlorogenic acid, quercetin and nilocitin, mainly found in the leaves. The in vitro antioxidant activity of different extracts of the Syzygium cumini leaves has been reported by different researchers (Ruan et al. 2008, Govaris et al. 2010, Ayyanar and SubashBabu 2012, Chandhary and Mukhopadhyay 2012, Nair et al. 2013, Kaneria and Chanda 2013, Reddy and Jose 2013, Siddiq et al. 2013). Mohamed et al. (2013) reported that the results, especially the antibacterial and antioxidant activity, should encourage investigations of using Syzygium cumini leaves as functional food and nutraceutical applications.

Given the above, a preliminary study was conducted to evaluate the effects of adding Syzygium cumini leaves (SCL) in laying hens diet on performance and egg quality.

\section{MATERIALS AND METHODS}

A trial was conducted in the Poultry Research Center of Animal Science Department at Ceará Federal University - Brazil. A total of 108 laying birds of Hysex White line with 69 weeks of age were housed in galvanized wire cages $(25 \times 40 \times 30 \mathrm{~cm})$ containing a feeder trough type and a nipple drinker each. The birds used in the assay were selected based on the weight $(1.503 \pm 0.177 \mathrm{~kg})$ and egg production $(84 \%)$ to obtain uniform experimental plots, according to Sakomura and Rostagno (2007). The laying hens were distributed in a completely randomized design with three treatments and six replicates of six birds, and the treatments consisted of Syzygium cumini leaves (SCL) inclusion at levels of 0,5 and $10 \mathrm{~g} / \mathrm{kg}$ in diets. To obtain the SCL, Syzygium cumini branches with leaves from different trees were harvested. Then the leaves were detached from the branches and submitted to sun drying. The leaves were spread onto plastic canvas and exposed to the sun for two consecutive days. After drying, the leaves were ground in a 1 $\mathrm{mm}$ sieve mill to be included in the rations. The experimental diets (Table I) were formulated to be isoenergetic and isonutritive, considering the nutritional requirements for Hysex White line recommendations and compositional values of feedstuffs proposed by Rostagno et al. (2011). The SCL was added to replace the inert in the rations.

The trial lasted 84 days, divided into four periods of 21 days each. Throughout the experiment, the birds received feed and water ad libitum and were subjected to a 16 -hour lighting program. The following performance variables were evaluated: feed intake (g/bird.day), egg production per bird per day (\%), egg weight (g), egg mass (g/bird.day) and feed conversion per egg mass ( $\mathrm{kg}$ of diet $/ \mathrm{kg}$ of eggs). The egg quality was assessed using the variables: Haugh unit, specific gravity, percentage of albumen, yolk and shell, shell thickness and yolk color. The analysis of eggs quality were taken once a week throughout the experimental period. For this, the eggs were collected from each replicate and three of them were randomly selected (avoiding broken, cracked or dirty eggs) to be analyzed.

The specific gravity was determined to obtain the density values of eggs as described by Freitas et al. (2004). The yolk color was performed through the Roche ${ }^{\circledR}$ color fan. To determine the proportions $(\%)$ of each constituent of the eggs, egg yolks were separated and weighed on a precision balance (Marte Científica $^{\mathrm{TM}}$ Model AD1000, max. $1010 \mathrm{~g}$ with precision $\pm 0.01 \mathrm{~g}$ ). Egg shells were washed and dried at $65{ }^{\circ} \mathrm{C}$ for a period of 48 hours and subsequently weighed. Yolk and shell proportions were obtained by the ratio of the weight of each portion and egg weight, while the albumen was 
TABLE I

Composition of diets according to SCL inclusion level.

\begin{tabular}{cccc}
\hline \multirow{2}{*}{$\begin{array}{c}\text { Feedstuffs }(\mathrm{g} / \mathrm{kg} \text { of } \\
\text { natural matter) }\end{array}$} & \multicolumn{3}{c}{$\mathrm{SCL}^{1}$ inclusion level $(\mathrm{g} / \mathrm{kg})$} \\
\cline { 2 - 4 } Corn & 627.0 & 627.0 & 627.0 \\
\hline Soybean meal (45\%) & 241.2 & 241.2 & 241.2 \\
Limestone & 88.3 & 88.3 & 88.3 \\
$\begin{array}{c}\text { Soybean oil } \\
\text { Monodicalcium } \\
\text { phosphate }\end{array}$ & 9.3 & 9.3 & 9.3 \\
$\begin{array}{c}\text { Mineral and vitamin } \\
\text { supplement }\end{array}$ & 3.0 & 3.0 & 3.0 \\
Salt $^{1}$ & 3.7 & 3.7 & 3.7 \\
DL-Methionine & 0.9 & 0.9 & 0.9 \\
SCL $^{2}$ & 0.0 & 5.0 & 10.0 \\
Inert $^{3}$ & 10.0 & 5.0 & 0.0 \\
\hline
\end{tabular}

Calculated nutritional and energy composition

\begin{tabular}{|c|c|c|c|}
\hline $\begin{array}{l}\text { Metabolizable energy } \\
(\mathrm{MJ} / \mathrm{kg})\end{array}$ & 11.55 & 11.55 & 11.55 \\
\hline Crude protein $(\mathrm{g} / \mathrm{kg})$ & 161.6 & 161.6 & 161.6 \\
\hline Calcium (g/kg) & 39.0 & 39.0 & 39.0 \\
\hline $\begin{array}{l}\text { Avaliable phosphorus } \\
\qquad(\mathrm{g} / \mathrm{kg})\end{array}$ & 4.0 & 4.0 & 4.0 \\
\hline Total phosphorus ( $\mathrm{g} / \mathrm{kg}$ ) & 6.0 & 6.0 & 6.0 \\
\hline Sodium $(\mathrm{g} / \mathrm{kg})$ & 1.8 & 1.8 & 1.8 \\
\hline Total lysine (g/kg) & 8.2 & 8.2 & 8.2 \\
\hline $\begin{array}{l}\text { Total methionine }+ \\
\text { cystine }(\mathrm{g} / \mathrm{kg})\end{array}$ & 6.9 & 6.9 & 6.9 \\
\hline Total methionine $(\mathrm{g} / \mathrm{kg})$ & 3.5 & 3.5 & 3.5 \\
\hline Total threonine $(\mathrm{g} / \mathrm{kg})$ & 6.3 & 6.3 & 6.3 \\
\hline Total tryptophan $(\mathrm{g} / \mathrm{kg})$ & 1.9 & 1.9 & 1.9 \\
\hline Linoleic acid (g/kg) & 18.7 & 18.7 & 18.7 \\
\hline
\end{tabular}

${ }^{1}$ Composition per kg: vitamin A: 2500000 IU, vitamin D3: $834000 \mathrm{IU}$, vitamin E: $2000 \mathrm{IU}$, vitamin $\mathrm{K} 3: 500 \mathrm{mg}$, vitamin B1: $334 \mathrm{mg}$, vitamin B2: $1500 \mathrm{mg}$, vitamin B6: $334 \mathrm{mg}$, vitamin B12: $3333 \mathrm{mg}$, niacin: $5000 \mathrm{mg}$, calcium pantothenate: $2000 \mathrm{mg}$, folic acid: $100 \mathrm{mg}$, biotin: $6.67 \mathrm{mg}$, choline: 50 g, methionine: 234 g, iron: $6660 \mathrm{mg}$, cupper: 2220 $\mathrm{mg}$, manganese: $20 \mathrm{~g}$, zinc: $17.34 \mathrm{~g}$, iodine: $400 \mathrm{mg}$, selenium: $100 \mathrm{mg}$, halquinol: $12 \mathrm{~g}$.

${ }^{2}$ Syzygium cumini leaves.

${ }^{3}$ Washed sand. determined by difference: albumen $=100$ - $($ yolk + shell). To evaluate the shell thickness, pieces were removed from the dried shell with membranes, one from each region of the shell (sharp pole, blunt pole and equatorial region). The thickness of each piece was measured with a micrometer (Mitutoyo ${ }^{\mathrm{TM}}$ with measurement of $0.01 \mathrm{~mm}$ and accuracy of $\pm 0.002 \mathrm{~mm}$ ). The average of the three measures was considered the shell thickness. Lipid oxidation was evaluated by thiobarbituric acid reactive substances (TBARS) in yolk. In the last week of the fourth period, the yolks of three eggs from each replicate were separated from the albumen and placed in a plastic container, homogenized and stored in a freezer $\left(-20^{\circ} \mathrm{C}\right)$ until the analyzes. After 60 days of storage, the yolks were thawed under refrigeration at $4{ }^{\circ} \mathrm{C}$ for 24 hours and then transferred to a beaker, homogenized and analyzed. The calibration curve and sample procedures for TBARS were carried out using the aqueous acid extraction method described by Kang et al. (2001). The number of TBARS sample was expressed as $\mathrm{mg}$ of malonaldehyde per $\mathrm{kg}$ of yolk.

Data were submitted to analysis of variance according to GLM procedure of SAS (2001). The normality and homogeneity of variances were checked for all variables by Shapiro-Wilk and Levene test, respectively, both at $5 \%$ of significance and the means were compared using SNK test at $5 \%$ of probability.

The experimental procedures followed the protocols approved by the Ethics Committee on Animal Research (CEPA 22/2013) of the Federal University of Ceará.

\section{RESULTS AND DISCUSSION}

The feed intake, egg production, egg weight, egg mass and feed conversion per egg mass were not remarkably affected by SCL inclusion at different levels in diets (Table II). 
TABLE II

Performance of laying hens fed diet with different levels of Syzygium cumini leaves (SCL).

\begin{tabular}{|c|c|c|c|c|c|}
\hline Treatments & Feed intake (g/bird.day) & $\begin{array}{c}\text { Egg } \\
\text { production (\%) }\end{array}$ & $\begin{array}{l}\text { Egg weight } \\
(\mathrm{g})\end{array}$ & $\begin{array}{l}\text { Egg mass (g/bird. } \\
\text { day) }\end{array}$ & $\begin{array}{l}\text { Feed conversion per } \\
\text { egg mass }(\mathrm{kg} / \mathrm{kg})\end{array}$ \\
\hline $0 \mathrm{~g} / \mathrm{kg}$ of $\mathrm{SCL}$ & 107.20 & 89.23 & 62.73 & 55.97 & 1.92 \\
\hline $5 \mathrm{~g} / \mathrm{kg}$ of SCL & 105.29 & 85.70 & 63.94 & 54.43 & 1.94 \\
\hline $10 \mathrm{~g} / \mathrm{kg}$ of $\mathrm{SCL}$ & 102.81 & 85.58 & 63.24 & 54.65 & 1.89 \\
\hline Means & 105.10 & 86.83 & 63.30 & 55.02 & 1.91 \\
\hline ANOVA effects & & & $p$-value & & \\
\hline Treatment & 0.5373 & 0.5786 & 0.2294 & 0.7933 & 0.7787 \\
\hline $\mathrm{CV}^{1}(\%)$ & 6.37 & 7.77 & 1.85 & 7.65 & 6.36 \\
\hline
\end{tabular}

${ }^{1}$ Coefficient of variation.

Feed intake is an important variable in monitoring commercial laying hens, since the productive performance of laying and egg quality, among other factors, depend on the availability of nutrients for the production processes. In turn, the availability of nutrients is usually ensured by daily feed intake by the birds. Thus, as the feed intake did not differ among treatments, the performance of laying hens fed the inclusion of SCL in the diet was similar to that of birds fed without the addition of SCL. The results obtained for the SCL inclusion on performance are similar to those reported by Botsoglou et al. (2012) whose evaluated olive leaves (Olea europea L.) in laying hens diets. These researchers affirmed that the addition of up to $10 \mathrm{~g} / \mathrm{kg}$ of olive leaves did not interfere in egg production, feed intake and egg weight. However, evaluating the addition of olive leaves in japanese quail (Coturnix coturnix japonica) diets, Christaki et al. (2011) found that the addition of up to $20 \mathrm{~g} /$ $\mathrm{kg}$ increased egg production without major effects on feed intake and egg weight.

Evaluating the egg quality and lipid oxidation of yolk (Table III), there was no significant effect of SCL inclusion on percentage of albumen, yolk and shell, Haugh unit, specific gravity and shell thickness. However, the egg yolk color was increased $(p<0.05)$ and a decrease on TBARS values $(p<0.05)$ was observed due to the rising levels of SCL. The birds fed diet containing $10 \mathrm{~g} /$ $\mathrm{kg}$ of SCL produced eggs with higher color value of yolk and lower TBARS value. The increase in yolk color of laying hens fed increasing levels of SCL can be explained by the higher amount of flavonoids in the diet, since these pigments represent the main group of phenolic compounds in SCL (Ruan et al. 2008). According to Garcia et al. (2009), the higher the intake of diets containing carotenoids and flavonoids by birds, the greater the deposition of pigment in the egg yolk and the intensity of the coloration.

In turn, the decrease in TBARS values in the yolk with SCL addition in diet indicates an antioxidant effect preventing peroxidation of yolk lipids. This effect can be associated to an antioxidant activity of different chemical compounds in the leaves of this plant as described by Migliato et al. (2006). Often, it has been reported in Syzygium cumini leaves extract the presence of phenolic compounds, besides flavonoids, saponins, steroids, and tannins (Nair et al. 2013) and the highest antioxidant activity of this is directly correlated 
TABLE III

Quality characteristics and lipid oxidation of yolk from laying hens fed diets with increasing levels of Syzygium cumini leaves (SCL).

\begin{tabular}{|c|c|c|c|c|c|c|c|c|}
\hline Treatments & $\begin{array}{c}\text { Albumen } \\
(\%)\end{array}$ & $\begin{array}{l}\text { Yolk } \\
(\%)\end{array}$ & $\begin{array}{l}\text { Shell } \\
(\%)\end{array}$ & $\begin{array}{c}\text { Haugh } \\
\text { unit }\end{array}$ & $\begin{array}{c}\text { Specific } \\
\text { gravity }\left(\mathrm{g} / \mathrm{cm}^{3}\right)\end{array}$ & $\begin{array}{l}\text { Shell thickness } \\
(\mathrm{mm})\end{array}$ & Yolk color $^{1}$ & $\begin{array}{l}\text { TBARS }^{2} \\
(\mathrm{mg} / \mathrm{kg})\end{array}$ \\
\hline $0 \mathrm{~g} / \mathrm{kg}$ of $\mathrm{SCL}$ & 65.87 & 25.91 & 8.80 & 79.20 & 1.078 & 0.33 & $6.79 \mathrm{c}$ & $0.50 \mathrm{a}$ \\
\hline $5 \mathrm{~g} / \mathrm{kg}$ of SCL & 65.56 & 25.79 & 8.98 & 76.57 & 1.078 & 0.34 & $7.12 b$ & $0.27 \mathrm{~b}$ \\
\hline $10 \mathrm{~g} / \mathrm{kg}$ of $\mathrm{SCL}$ & 65.17 & 25.94 & 9.03 & 76.03 & 1.075 & 0.34 & $7.91 \mathrm{a}$ & $0.12 \mathrm{c}$ \\
\hline Means & 65.53 & 25.88 & 8.94 & 77.27 & 1.077 & 0.34 & 7.27 & 0.29 \\
\hline ANOVA effects & & & & & $p$-value & & & \\
\hline Treatment & 0.473 & 0.951 & 0.505 & 0.289 & 0.356 & 0.341 & 0.001 & 0.001 \\
\hline $\mathrm{CV}^{3}(\%)$ & 1.49 & 3.19 & 3.96 & 4.63 & 0.36 & 4.24 & 2.04 & 3.78 \\
\hline
\end{tabular}

Means followed by different letters in the same column are different by SNK test at $5 \%$ of probability. ${ }^{1}$ Roche ${ }^{\circledR}$ color fan. ${ }^{2}$ Thiobarbituric acid reactive substances. ${ }^{3}$ Coefficient of variation.

with its phenolic compounds (Reddy and Jose 2013). In addition, Ruan et al. (2008) observed high content of catechin and ferulic acid, affirming that besides phenolic acids, the other complex phenolic compounds in SCL may also be responsible for the antioxidant activity. Nair et al. (2013) affirmed that not only these compounds present antioxidant effect and the high proportion of active compounds can also be due to the presence of other constituents in small amounts or the synergy among them. Moreover, the effects of flavonoids in the cells may be related to the interaction of specific proteins, which are essential for inhibiting a signaling intracellular cascade (Schroeter et al. 2002).

The results obtained with SCL inclusion on egg quality resemble, in part, to those reported in the literature to include plant leaves with proven in vitro antioxidant activity. The inclusion of olive leaves (Olea europea L.) in japanese quail diets was evaluated by Christaki et al. (2011) observing that the addition of up to $20 \mathrm{~g} / \mathrm{kg}$ improved the color of the yolk. In turn, Botsoglou et al. (2012) evaluated laying hens producing enriched omega-3 eggs and noted the benefit of adding $10 \mathrm{~g} / \mathrm{kg}$ of olive leaves (Olea europea L.) in diet on lipid stability of yolk, which presented the lowest value for TBARS. In this sense, studies evaluating the in vitro antioxidant activity of SCL have demonstrated that, both in DPPH free-radical scavenging activity and ferric reducing power trials, the active components of medium polarity, such as flavonoids quercetin and myricetin, present high correlation with antioxidant action (Ruan et al. 2008, Sultana et al. 2009), and thus resulted in lower TBARS values as observed in this study. According to the results observed by Sultana et al. (2007) when comparing inhibition of linoleic acid oxidation of four different plants, the phenolic compounds present in the SCL had higher antioxidant activity, demonstrating the potential protective effect of flavonoids on polyunsaturated fatty acids, in order to greater participation of these in enriched eggs.

\section{CONCLUSION}

The inclusion of Syzygium cumini leaves in laying hens diet at levels of up to $10 \mathrm{~g} / \mathrm{kg}$ improves the color and lipid stability of egg yolk, without harming the performance and quality of albumen and egg shell. 


\section{REFERENCES}

AHN J, GRUN IU AND FERNANDO LN. 2002. Antioxidant properties of natural plant extracts containing polyphenolic compounds in cooked ground beef. J Food Sci 64: 13641369.

AYYANAR M AND SUBASH-BABU P. 2012. Syzygium cumini (L.) Skeels: A review of its phytochemical constituents and traditional uses. Asian Pac J Trop Biomed 2: $240-246$

BOTSOGLOU E, GOVARIS A, FLETOURIS D AND ILIADIS S. 2012. Olive leaves (Olea europea L.) and $\alpha$-tocopheryl acetate as feed antioxidants for improving the oxidative stability of $\alpha$-linolenic acid-enriched eggs. J Anim Physiol Anim Nutr 94: 740-753.

CHANDHARY B AND MUKHOPADHYAY K. 2012. Syzygium cumini (L.) skeels: a potential source of nutraceuticals. Int J Pharm Pharm Sci 2: 46-53.

CHRISTAKI E, BONOS E AND FLOROU-PANERI P. 2011. Effect of dietary supplementation of olive leaves and/or $\alpha$-tocopheryl acetate on performance and egg quality of laying japanese quail (Coturnix japonica). Asian J Anim Vet Adv 6: 1241-1248.

FREITAS ER, BORGES AS, TREVISAN MTS, CUNHA AL, BRAZ NM, WATANABE PH AND NASCIMENTO GAJ. 2013. Extratos etanólicos da manga como antioxidantes na alimentação de poedeiras. Pesq Agropec Bras 48: 714-721.

FREITAS ER, SAKOMURA NK, GONZALES MM AND BARBOSA NAA. 2004. Comparação de métodos de determinação da gravidade específica de ovos de poedeiras comerciais. Pesq Agropec Bras 39: 509-512.

GARCIA RG, MOLINO AB, BERTO DA, PELÍCIA K, OSERA RH AND FAITARONE ABG. 2009. Desempenho e qualidade dos ovos de poedeiras comerciais alimentadas com semente de Urucum (Bixa orellana L.) moída na dieta. Vet Zootec 16: 689-697.

GOVARIS A, BOTSOGLOU E, MOULAS A AND BOTSOGLOU N. 2010. Effect of dietary olive leaves and rosemary on microbial growth and lipid oxidation of turkey breast during refrigerated storage. S Afr J Anim Sci 40: 145-155.

KANERIA M AND CHANDA S. 2013. Evaluation of antioxidant and antimicrobial capacity of Syzygium cumini leaves extracted sequentially in different solvents. J Food Biochem 37: 168-176.

KANG KR, CHERIAN G AND SIM JS. 2001. Dietary palm oil alters the lipid stability of polyunsaturated fatty acid-modified poultry products. Poult Sci 80 : 228-234.
MARIUTTI LRB AND BRAGAGNOLO NA. 2009. Oxidação lipídica em carne de frango e o impacto da adição de sálvia (Salvia officinalis, L.) e de alho (Allium sativum, L.) como antioxidantes naturais. Rev Inst Adolfo Lutz 68: 1-11.

MIGLIATO KF, BABY AR, ZAGUE V, VELASCO MVR, CORREAA MA, SACRAMENTO LVS AND SALGADO HRN. 2006. Ação farmacológica de Syzygium cumini (L.) skeels. Acta Farm Bonaerense 25: 310-314.

MOHAMED AA, ALI SI AND EL-BAZ FK. 2013. Antioxidant and antibacterial activities of crude extracts and essential oils of Syzygium cumini leaves. PLoS ONE 8: 1-7.

NAIR LK, BEGUM M AND GEETHA S. 2013. In vitroantioxidant activity of the seed and leaf extracts of Syzygium cumini. J Envir Sci Toxicol Food Technol 7(1): 54-62.

REDDY LJ AND JOSE B. 2013. Evaluation of antibacterial and DPPH radical scavenging activities of the leaf extracts and leaf essential oil of Syzygium cumini Linn. from South India. Int J Pharm Pharm Sci 5: 358-361.

ROSTAGNO HS, ALBINO LFT, DONZELE JL, GOMES PC, OLIVEIRA RF, LOPES DC, FERREIRA AS AND BARRETO SLT. 2011. Tabelas Brasileiras para aves e suínos: composição de alimentos e exigências nutricionais, $3^{\mathrm{a}}$ ed., Viçosa, MG: UFV, 252 p.

RUAN ZP, ZHANG LL AND LIN YM. 2008. Evaluation of the antioxidant activity of Syzygium cumini leaves. Molecules 13: 2545-2556.

SAKOMURA NK AND ROSTAGNO HS. 2007. Métodos de pesquisa em nutrição de monogástricos. Jaboticabal, SP: Funep, $283 \mathrm{p}$.

SAS - STATISTICAL ANALYSIS SYSTEM. 2001. User's guide, version 8.2. SAS Institute (INC. Cary. NC. USA)

SCHROETER H, BOYD C, SPENCER JPE, WILLIAMS R, CADENAS E AND RICE-EVANS C. 2002. MAPK signaling in neurodegeneration: influences of flavonoids and nitric oxide. Neurobiol Aging 23: 861-880.

SIDDIQ M, SOGI DS AND DOLAN KD. 2013. Antioxidant properties, total phenolics, and quality of fresh-cut 'Tommy Atkins' mangoes as affected by different pre-treatments. LWT - Food Sci Technol 53: 156-162.

SULTANA B, ANWAR F AND ASHRAF M. 2009. Effect of extraction solvent/technique on the antioxidant activity of selected medicinal plant extracts. Molecules 14: 21672180 .

SULTANA B, ANWAR F AND PRZYBYLSKI R. 2007. Antioxidant activity of phenolic components present in barks of Azadirachta indica, Terminalia arjuna, Acacia nilotica, and Eugenia jambolana Lam. trees. Food Chem 104: 1106-1114. 